\title{
PERILAKU KEUANGAN MASYARAKAT KAMPUNG DI MERAUKE
}

\author{
Imelda C. Laode $^{1}$,Irine Herdjiono ${ }^{2}$, Eka Juni Martanti ${ }^{3}$ \\ ${ }^{1}$ Jurusan Manajemen, Universitas Musamus \\ Email: imelda.laode@ rocketmail.com \\ ${ }^{2}$ Jurusan Akuntansi, Universitas Musamus \\ Email:irene.herdjiono@gmail.com \\ ${ }^{3}$ Jurusan Akuntansi, Universitas Musamus \\ Email: martantiekajuni@gmail.com
}

\begin{abstract}
ABSTRAK
Penelitian ini bertujuan untuk memperoleh gambaran bagaimana perilaku keuangan masyarakat kampung di Merauke.Manfaat dari penelitian ini adalah dapat menjadi bahan pertimbangan penyusunan kebijakan dan program pengembangan ekonomi di kampung menuju masyarakat mandiri.Data diperoleh melalui kuesioner, wawancara dan pengamatan.Analisis data menggunakan analisis deksriptif.

Informan penelitian ini berjumlah 75 orang dari empat kampung yaitu, Zenegi, Baad, Sermayam dan Onggari.Berdasarkan data dan analisis, perilaku keuangan masyarakat kampung dalam hal penganggaran, pengelolaan kas dan menabung masih rendah. Terdapat perbedaan perilaku menabung masyarakat pada kampung yang lebih maju daripada kampung yang lain yaitu perilaku keuangannya lebih baik. Kampung yang lebih maju ini lebih banyak dihuni oleh pendatang, dalam hal ini bukan masyarakat asli serta aktivitas perekonomiannya lebih berkembang pada kampung dengan masyarakat yang perilaku keuangannya lebih baik.
\end{abstract}

Kata kunci: kampung, merauke, perilaku keuangan

\section{PENDAHULUAN}

Fokus pembangunan Indonesia saat ini adalah pada daerah perbatasan atau yang biasa disebut pembangunan dari pinggiran. Berdasarkan Peraturan Presiden Nomor 2 Tahun 2015 salah satu agenda prioritas pembangunan tahun 2015-2019 adalah membangun Indonesia dari pinggiran dengan memperkuat daerah-daerah dan desa dalam kerangka Negara kesatuan.Kebijakan terkait dengan fokus pembangunan dari pinggiran adalah upaya pemerintah mendorong kemandirian ekonomi desa.

Data BPS September 2015 propinsi dengan jumlah penduduk miskin terbanyak adalah Papua.Ditinjau lebih rinci lagi kemiskinan di desa lebih tinggi daripada di perkotaan. Jumlah penduduk miskin di perkotaan mencapai 3,61 \% sedangkan di desa mencapai 37,34\%. Di Papua wilayah desa dan wilayah kampung lebih banyak dihuni oleh masyarakat asli Papua.Ketimpangan yang semakin besar antar propinsi dan antar etnis menjadi ancaman yang serius dalam menunjang pembangunan.

Tabel.1

Penduduk Miskin di Kabupaten Merauke, 2008-2013

\begin{tabular}{ccc}
\hline Tahun & Jumlah Penduduk Miskin & Garis Kemiskinan (Rp/Kap/Bln) \\
\hline 2008 & 26.680 & 189.428 \\
2009 & 26.510 & 212.148 \\
2010 & 28.500 & 230.729 \\
2011 & 27.580 & 241.904 \\
2012 & 28.500 & 253.620 \\
2013 & 26.000 & 261.300 \\
\hline & Sumber:Kabupaten Merauke dalam Angka, 2015
\end{tabular}

Di Kabupaten Merauke baik di daerah perkotaan maupun didaerah perdesaan, pengeluaran rumah tangga tidak ada yang dibawah Rp.100.000 setiap bulannya. Mayoritas penduduk yang berada di wilayah perkotaan memiliki pengeluaran diatas Rp. 900.000. Berbeda dengan penduduk yang bertempat tinggal di wilayah perdesaan, pengeluaran rata-rata setiap bulannya antara Rp.100.000 hingga Rp.299.999. 
Pada tahun 2014, pengeluaran rata-rata per kapita yang dilakukan oleh rumah tangga di Kabupaten Merauke didominasi oleh rumah tangga dengan pengeluaran Rp 300.000,- Rp 499.999 sebanyak 21 persen. Sedangkan pengeluaran rata-rata per kapita yang mencapai $\mathrm{Rp}$ 700.000-Rp 899.999 hanya sebanyak 9 persen.

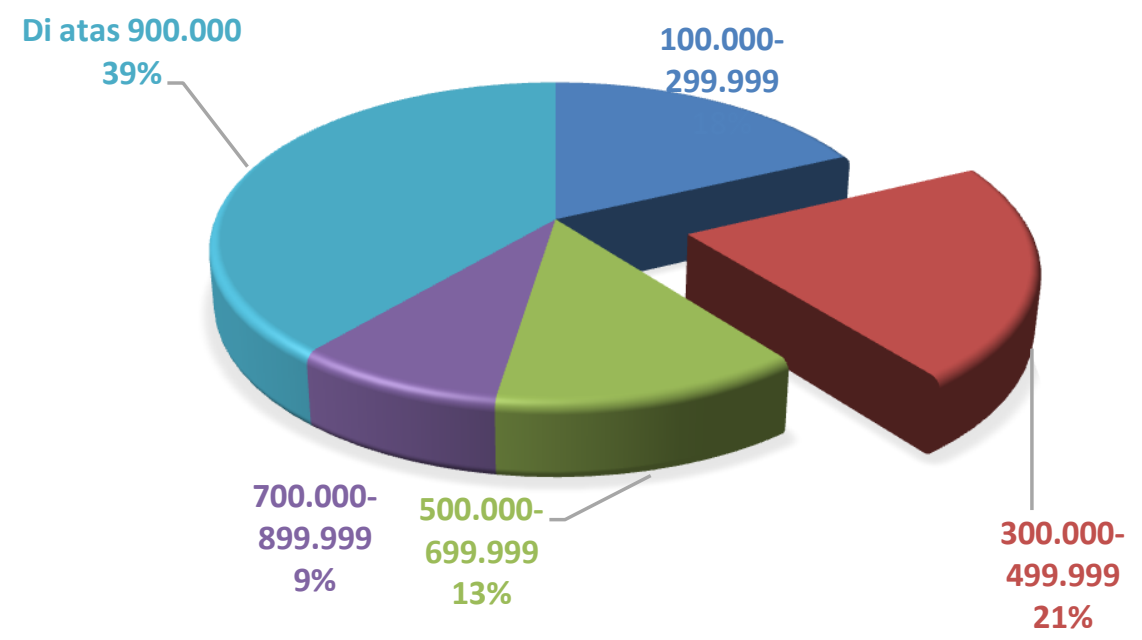

Gambar 1.Persentase Rumah Tangga Menurut Pengeluaran Rata-rata per Kapita di Kabupaten Merauke

Sumber: Kabupaten Merauke dalam Angka, 2014.

Tingginya kemiskinan atau dengan kata lain rendahnya kemampuan keuangan menjadi salah satu alasan berkembangnya program financial literacy khususnya di negara dengan middle income dan low income. World bank mengkategorikan negara dengan low income apabila Gross National Income (GNI) per capita dibawah \$1.026 dan Negara dengan middle income apabila GNI antara \$.1026 sampai \$12.746.

Karakteristik di negara middle income dan low income adalah rendahnya akses keuangan dibandingkan dengan jumlah penduduk, tingginya kemiskinan, lokasi yang terpisah-pisah dan banyaknya tenaga kerja yang tidak memiliki skill, lisensi. Karakteristik-karakteristik tersebut mendorong perlunya financial literacy di negara middle income dan low income.

Financial management behavior adalah kemampuan seseorang dalam mengatur yaitu perencanaan, penganggaran, pemeriksaan, pengelolaan, pengendalian, pencarian dan penyimpanan dana keuangan sehari-hari (Kholilah dan Iramani, 2013). Munculnya financial managementbehavior, merupakan dampak dari besarnya hasrat seseorang untuk memenuhi kebutuhan hidupnya sesuai dengan tingkat pendapatan yang diperoleh (Kholilah dan Iramani, 2013).

Financial managementbehavior berhubungan dengan tanggung jawab keuangan seseorang mengenai cara pengelolaan keuangan mereka. Tanggung jawab keuangan adalah proses pengelolaan uang dan aset lainnya dengan cara yang dianggap produktif. Pengelolaan uang atau managemen uang adalah proses menguasai dalam hal penggunaan aset keuangan.

Penelitian mengenai perilaku keuangan masyarakat low income dilakukan oleh Demosthenous et al.(2006). Dalam penelitian tersebut disimpulkan bahwa faktor sosial budaya menentukan perilaku pengelolaan keuangan masyarakat aborigin. Masyarakat aborigin tidak terbiasa 
menabung karena adanya anggapan bahwa menabung adalah perilaku yang mementingkan diri sendiri.

Sejumlah penelitian mengenai perilaku keuangan dilakukan oleh Lusardi (2005), Alamil dan Seauperii (2012). Alamis dan Sauperii (2012) mengkaji perilaku menabung pegawai sektor swasta dan pemerintah di Papua New Guinea dan menyimpulkan tradisi masyarakat lokal untuk membantu keluarga, pengeluaran keluarga, dan jumlah keluarga menjadi faktor utama yang mempengaruhi perilaku menabung. Faktor ekonomi yang mempengaruhi perilaku menabung diantaranya adalah untuk berjaga-jaga kebutuhan di masa depan, membayar hutang, membuka usaha baru, persiapan pension dan untuk berlibur. Lusardi (2005) menyimpulkan bahwa perilaku keuangan khususnya dalam hal menabung dipengaruhi oleh factor dikriminasi dan budaya dan adanya perilaku yang sangat berbeda antara ras kulit putih dan ras Africa-Amerika, Hispanic.Lusardi (2005) menyarankan untuk program pendidikan keuangan yang dilakukan oleh pemerintah difokuskan pada strategi perencanaan keuangan yang paling dasar dan difokuskan pada kebutuhan masyarakat tersebut.

Sampai saat penelitian ini ditulis belum ada penelitian secara empiris mengenai perilaku keuangan masyarakat di Merauke terutama daerah kampung.Gambaran perilaku keuangan secara komprehensif ini sangat penting karena dapat mendukung perumusan kebijakan serta penyusunan program yang tepat dalam upaya pembangunan ekonomi. Masalah yang akan diangkat dalam penelitian ini adalah bagaimana perilaku keuangan masyarakat kampung di Merauke.

\section{METODE PENELITIAN}

Jenis penelitian ini adalah penelitian kualitatif.Subyek penelitian adalah masyarakat di sejumlah kampung di Merauke dan obyek penelitian adalah perilaku manajemen keuangan.Penelitian ini menggunakan data primer berupa kuesioner.Disamping kuesioner juga dilakukan wawancara dan pengamatan langsung.

Analisis data dilakukan melalui beberapa tahap, yaitu:

a. Melakukan analisis deksriptif berdasarkan tabulasi data

b. Melakukan analisis secara komprehensif berdasarkan analisis deskpritif, pengamatan, dan teori.

Pertanyaan yang diajukan dalam kuesioner akan dinilai dengan penilaian: selalu mendapat nilai 5, sering mendapat nilai 4, kadang-kadang mendapat nilai 3, sangat jarang mendapat nilai 2 dan tidak pernah mendapat nilai 1.Pengolahan data menggunakan excel.

\section{HASIL DAN PEMBAHASAN}

\section{A. DESKRIPSI DATA}

\section{Lokasi Pengampulan Data}

Data penelitian diambil dari empat lokasi, yaitu Sermayam, Zanegi, Baad dan Onggari.Perincian data dari masing-masing lokasi dapat ilihat pada Tabel 4.1. 
Tabel 4.1. Lokasi dan Jumlah Responden

\begin{tabular}{lll}
\hline No. & Lokasi & $\begin{array}{l}\text { Jumlah } \\
\text { Responden }\end{array}$ \\
\hline 1. & Sermayam & 17 \\
2. & Zanegi & 21 \\
3. & Baad & 17 \\
4. & Onggari & 20 \\
\hline & Total & 75 \\
\hline
\end{tabular}

Sumber data : Kuesioner

Berdasarkan Tabel 4.1 jumlah responden pada kampung Sermayam sebanyak 17 orang, kampong Zanegi sebanyak 21 orang, Kampung Baad 17 orang dan Kampung Onggari 20 orang.

\section{Gambaran Umum Kampung}

Gambaran Umum keempat kampung yang menjadi lokasi penelitian dapat dilihat pada Tabel 4.2.

Tabel 4.2. Kondisi Kampung

\begin{tabular}{|c|c|c|c|c|c|}
\hline & & & & & \\
\hline No & Keterangan & Sermayam & Zanegi & Baad & Onggari \\
\hline 1. & $\begin{array}{l}\text { Lokasi } \\
\text { Distrik }\end{array}$ & Tanah Miring & Animha & Animha & Malind \\
\hline 2. & $\begin{array}{l}\text { Mata } \\
\text { pencaharian }\end{array}$ & $\begin{array}{l}\text { Petani, } \\
\text { Wiraswasta, } \\
\text { PNS }\end{array}$ & $\begin{array}{l}\text { Berburu, } \\
\text { meramu, } \\
\text { petani }\end{array}$ & $\begin{array}{l}\text { Berburu, } \\
\text { meramu, } \\
\text { petani }\end{array}$ & $\begin{array}{l}\text { Nelayan, } \\
\text { berkebun }\end{array}$ \\
\hline 3. & Hasil Alam & $\begin{array}{l}\text { Padi, jeruk, } \\
\text { ubi, sayur, } \\
\text { ikan gastor }\end{array}$ & $\begin{array}{l}\text { Umbi, buah } \\
\text { genetri }\end{array}$ & $\begin{array}{l}\text { Umbi, buah } \\
\text { genetri }\end{array}$ & Ikan \\
\hline 4. & Suku & Jawa & Yei, Marind & Marind & Marind \\
\hline
\end{tabular}

Sumber data : Pengamatan, wawancara dan kuesioner

\section{B. ANALISIS DATA}

1. PERILAKU PENGANGGARAN

Perilaku pengganggaran diklasifikasikan menjadi tiga yaitu (1) perilaku membuat pertimbangan ketika membeli,(2) membuat perencanaan masa depan, (3) membuat anggaran keuangan.

Tabel 4.3. Perilaku Penganggaran

\begin{tabular}{llccccc}
\hline No. & JENIS PERILAKU & \multicolumn{5}{c}{ Kategori (orang) } \\
\cline { 3 - 7 } & PENGANGGARAN & $\mathbf{1}$ & $\mathbf{2}$ & $\mathbf{3}$ & $\mathbf{4}$ & $\mathbf{5}$ \\
\cline { 3 - 7 } 1. & Pertimbangan Membeli & 16 & 8 & 30 & 6 & 15 \\
2. & Rencana Masa Depan & 27 & 9 & 23 & 8 & 8 \\
3. & Membuat Anggaran & 29 & 10 & 22 & 10 & 4 \\
\hline
\end{tabular}

Sumber data : Kuesioner

Berdasarkan Tabel 4.3 diatas perilaku penganggaran dalam hal pertimbangan membeli mayoritas jawaban responden ada pada kategori 3 atau kadang-kadang resonden membuat pertimbangan pembelian. Pada perilaku membuat perencanaan masa depan, mayoritas jawaban responden adalah pada kategori satu atau sebagian besar responden tidak membuat perencanaan masa depan. Pada perilaku membuat aggaran, mayoritas jawaban responden adalah pada kategori satu atau sebagian besar responden tidak membuat anggaran. Secara umum ketiga perilaku penganggaran 
cenderung berada pada kategori 1,2 dan 3 atau dengan kata lain perilaku penganggaran masih rendah.

2. Perilaku Pengelolaan Kas

Perilaku pengelolaan kas dibagi menjadi 3 yaitu (1) membayar tagihan bulanan atau tahunan tepat waktu, (2)memperhatikan bukti pembayaran, (3) ikut mengambil keputusan saat pengeluaran uang.

Tabel 4.4. Perilaku Pengelolaan Kas

\begin{tabular}{l|lccccc}
\hline No. & JENIS PERILAKU & \multicolumn{5}{c}{ Kategori (orang) } \\
\cline { 3 - 6 } & PENGELOLAAN KAS & $\mathbf{1}$ & $\mathbf{2}$ & $\mathbf{3}$ & $\mathbf{4}$ & $\mathbf{5}$ \\
\hline 1. & Membayar Tagihan Tepat Waktu & 21 & 5 & 27 & 15 & 7 \\
2. & Memperhatikan Bukti Pembayaran & 24 & 12 & 31 & 5 & 3 \\
3. & Keputusan Pengeluaran Uang & 25 & 8 & 30 & 4 & 8 \\
\hline
\end{tabular}

Sumber data : Kuesioner

Berdasarkan tabel diatas perilaku pengelolaan kas dalam hal membayar tagihan tepat waktu, peringkat pertama terbanyak responden menjawab 3 atau kadang-kadang responden membayar tagihan tepat waktu.Pada perilaku memperhatikan bukti pembayaran, jumlah resonden tertinggi menjawab kategori 3 atau kadang-kadang responden memperhatikan bukti pembayaran.Pada perilaku membuat keputusan pengeluaran uang, jumlah resonden tertinggi menjawab kategori 33 atau kadangkadang membuat keputusan pengeluaran keuangan. Secara umum kecenderungan ketiga perilaku diatas adalah tidak pernah atau jarang atau dengan kata lain pengelolaan kas masih rendah.

3. Perilaku Menabung

Perilaku menabung responden dapat dilihat pada Tabel 4.5.

Tabel 4.5. Perilaku Penganggaran

\begin{tabular}{llccc}
\hline No. & JENIS PERILAKU & \multicolumn{3}{c}{ Kategori (dalam \%) } \\
\cline { 2 - 4 } & MENABUNG & Ya & Tidak & $\begin{array}{l}\text { Tidak } \\
\text { Tahu }\end{array}$ \\
\hline 1. & Menabung & 18 & 55 & 27 \\
\hline
\end{tabular}

Berdasarkan Tabe14.12. Sebanyak $55 \%$ responden tidak menabung dalam satu tahun terakhir.

\section{PEMBAHASAN}

1. Perilaku keuangan dalam hal Penganggaran.

Perilaku yang terkait dengan penganggaran adalah membuat pertimbangan ketika membeli, membuat perencanaan masa depan, membuat anggaran keuangan. Berdasarkan analisis data, perilaku penganggaran masyarakat di empat kampung masih rendah, dimana sebagian besar informan menjawab tidak pernah, sangat jarang dan kadang-kadang pada pertanyaan terkait perilaku penganggaran.

Rendahnya perilaku penganggaran ditentukan oleh faktor keluarga. Webley dan Nyhus (2006) menyatakan bahwa sosialisasi ekonomi seperti berdiskusi masalah keuangan antara orang tua dan anak akan menentukan orientasi masa depan anak. Dengan kata lain anak yang memiliki hubungan yang yang baik dalam keluarga akan memiliki orientasi masa depan dan berperilaku keuangan yang baik. Walker (1996) 
menyimpulkan bahwa kondisi anggaran yang stabil berhubungan dengan kepuasan ekonomi yang lebih baik.Seseorang yang sering berdiskusi mengenai keuangan dengan keluarga maupun teman cenderung menunjukkan perilaku keuangan dalam hal penganggaran yang baik.

Faktor sosial menentukan perilaku penggaran terjadi karena adanya proses pembelajaran ketika interaksi. Faktor pembelajaran ini yang akan ikut menentukan faktor individu seperti self efficacy yang tinggi, berorientasi masa depan dan lebih cenderung tidak bersifat materialisme.

Kondisi masyarakat pada empat kampung yang menjadi lokasi penelitian secara umum menunjukkan kondisi yang sama, yaitu memiliki keterbatasan dalam hal membuat perencanaan untuk masa depan dan membuat anggaran. Keterbatasan ini dapat dipahami mengingat masyakatnya, yang pada umumnya merupakan masyarakat adat, kondisi sosial ekonomi belum berkembang.Berdasarkan Australian Securities and Investment Commission (ASIC, 2013) masyarakat adat atau biasa disebut indigenous people memilik keterbatasan (1) tidak dapat menyusun anggaran, tidak dapat mengidentifikasi produk keuangan dan jasa dalam rangka memenuhi kebutuhannya, (3) tidak memperoleh arahan kemandirian di bidang keuangan dan (4) tidak pahamhak kosumennya. Oleh karena itu diperlukan dua hal yaitu mengajarkan bagaimana memperoleh uang dan mengelola uang (Sallik et al., 2004)

Melihat lebih dalam kondisi dari keempat lokasi, masyarakat di Sermayam dapat dikatakan memiliki kemampuan penganggaran yang lebih baik dibandingkan ketiga kampung yang lain yaitu Zanegi, Baad dan Onggari.

Faktor self efficacy dan perilaku penganggaran bersifat asosiatif atau timbal balik. Seseorang yang biasa melakukan penganggaran akan merasa memiliki kendali atas situasi yang dihadapinya. Seseorang yang berpikir akan masa depan akan cenderung berpikir jangka panjang dalam setiap aktivitasnya.Hal ini sejalan dengan hasil penelitian Herdjiono dan Damanik (2016).

2. Perilaku Pengelolaan Kas

Perilaku pengelolaan kas diidentifikasi dari 3 hal yaitu membayar tagihan tepat waktu, memperhatikan bukti pembayaran dan ikut terlibat membuat keputusan pada saat pengeluaran uang.Berdasarkan analisis data ketiga perilaku menunjukkan tingkat yang rendah.

Hogarth dan Hilgert (2003) menjelaskan bahwa pengetahuan keuangan menunjukkan perilaku pengelolaan kas yang rendah.Semakin rendah pengetahuan keuangan maka perilaku pengelolaan kas juga rendah.

3. Perilaku Menabung

Perilaku menabung responden di empat kampung rata-rata masih rendah, dimana hal ini terlihat dari sebanyak 55\% responden menjawab tidak menabung.Sejumlah penelitian menjelaskan rendahnya perilaku menabung karena rendahnya literasi keuangan (Lusardi, Mitchell, 2007; Mahdan, Tabiani, 2013).Literasi keuangan merupakan pengetahuan tentang keuangan dan sangat erat kaitannya dengan pendidikan seseorang.Rata-rata pendidikan di kampung masih rendah.Masih banyak 
masyarakat kampung yang belum dapat membaca, menulis dan berhitung.Hal ini menunjukkan bahwa tingkat pendidikan dan literasi keuangan masih rendah.Hogarth (2002) membuktikan bahwa semakin tinggi tingkat pendidikan seseorang semakin mampu mengelola uang seperti asurasi, investasi, menabung dan membuat anggaran.

Perilaku menabung selain ditentukan oleh financial literacy, juga ditentukan oleh faktor sosial seperti keluarga dan kerabat (Jamal et al., 2015).Shim et. al(2010) menyimpulkan bahwa pengaruh orang tua lebih besar daripada pengalaman kerja dan pendidikan keuangan di tingkat pendidikan menangah atas. Orang tua yang memiliki perilaku keuangan yang baik akan menjadi role model bagi anaknya dan akan menjadi pendorong perilaku keuangan yang baik.

Faktor sosial dalam hal ini kerabat atau masyarakat dapat menentukan perilaku keuangan individu. Duflo and Saez (2001) menyatakan bahwa orang akan cenderung berkumpul dengan orang lain yang berperilaku sama. Mereka menyimpulkan bahwa peerberperan penting dalam keputusan menabung untuk pensiun.

\section{Perilaku Keuangan Berdasarkan Socialization Theory dan Social Cognitive Theory} Konsep sosial meliputi adanya pengetahuan, keahlian dan nilai yang memungkinkan seorang individu berinteraksi satu sama lain dalam suatu sistem sosial (Ozmete, Tahira, 2011). Perilaku keuangan berdasarkan Socialization Theory adalah ditentukan oleh proses pembelajaran.

Learning processdalam kehidupan sosial adalah nilai, perilaku, standard, norma, pengetahuan dan perilaku yang ditransfer dari satu agen ke agen lainnya. Agen yang berperan memindahkan nilai, perilau, standard, norma, pengetahuan dan perilaku adalah agen formal seperti pemerintah, sekolah, keluarga, agen informal seperti masyarakat, media masa.

Lebih lengkap menjelasakan bagaimana faktor sosial menentukan perilaku individu adalah Social Cognitive Theory.Berdasarkan Social Cognitive Theory terdapat tiga hal yang saling berhubungan yaitu faktor individu masing-masing, lingkungan dan perilaku. Pengaruh lingkungan, keluarga sekolah akan menentukan pengetahuan dan nilai tentang keuangan yang nantinya akan mempengaruhi perilaku dalam mengelola keuangan (Jorgensen, 2007). Herdjiono dan Damanik (2016) menyimpulkan bahwa faktor attitude berpengaruh terhadap perilaku keuangan, dimana financial attitude yang baik seperti bagaimana persepsinya akan masa depan akan menentukan perilakunya dalam hal menabung.

Berdasarkan teori dan hasil penelitian model perilaku keuangan masyarakat kampung dapat digambarkan sebagai berikut: 


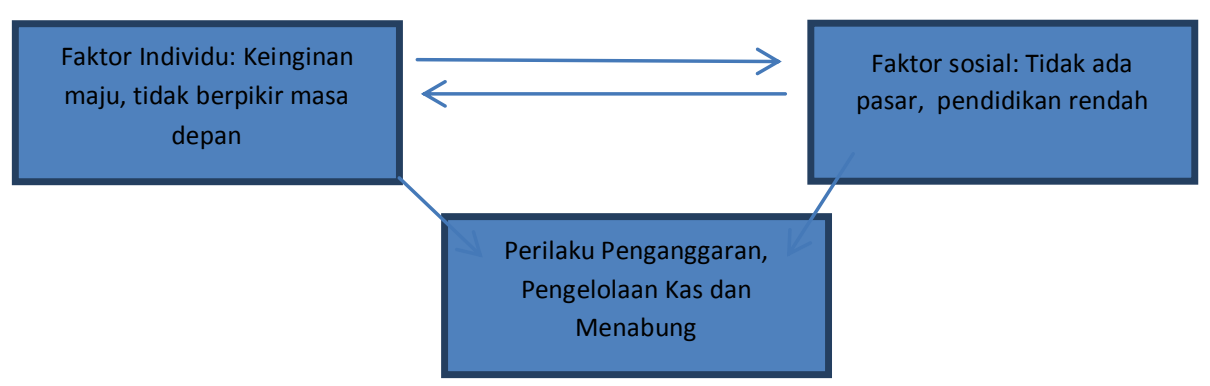

Gambar 2. Model Perilaku Keuangan Masyarakat Kampung

\section{KESIMPULAN}

Berdasarkan pembahasan diatas dapat disimpulkan bahwa perilaku keuangan masyarakat dalam hal penganggaran, pengelolaan kas serta menabung pada 4 kampung di Merauke masih belum mencerminkan perilaku yang baik, yaitu tidak menyusun anggaran, memiliki tabungan serta belum mengelola kas dengan baik. Ditinjau lebih jauh lagi, dari keempat kampung yang menjadi lokasi penelitian, kampung Sermayam yang memiliki penduduk mayoritas suku non Papua memiliki perilaku keuangan yang lebih baik.Hal ini juga ditunjang dengan kondisi perekonomian yang lebih maju dengan adanya pasar di kampung Sermayam, penghasilan yang lebih besar, mata pencaharian yang relatif lebih maju.

Penelitian mengenai keuangan berkembang kearah kajian perilaku atau disebut behavioral finance.Penelitian ini memperkaya penelitian di bidang behavioral finance khususnya pada lingkup individu.

Keterbatasan penelitian ini adalah lokasi penelitian hanya berfokus pada 4 kampung.Penelitian selanjutnya dapat memperluas wilayah penelitian serta mengkaji lebih dalam bagaimana perilaku keuangan berhubungan dengan financial wellbeing pada masyarakat kampung.

\section{REFERENSI}

Alamil.Luis R. and Julius Danny Sauperii.(2012). Financial savings disposition and behaviour of private and public sector employees in PNG. Contemporary PNG Studies, Vol 17: 94-11

Australian Securities and Investment Commission (ASIC).(2003). Financial Literacy n Schools: ASIC discussion paper. Canberra: Australian Government Publishing Service

Demosthenous, Catherine, Boni Robertson, Anuja Cabraal, Supriya Singh. (2006). Cultural Identity and Financial Literacy: Australian Aboriginal Experiences of Money and Money Management. Financial Literacy, Banking and Identity Conference25th and 26th October 2006, Storey HallRMIT University, Melbourne

Duflo, E., \& Saez, E. (2002). Participation and investment decisions in a retirement plan: The influence of colleagues' choices. Journal of public Economics, 85(1), 121-148.

Herdjiono, Irine \& Lady. A. Damanik (2016). Pengaruh Financial Attitude, Financial Knowledge, Parental Income terhadap Financial Management Behavior.Jurnal Manajemen Teori dan Terapan. Tahun 9 No.3: 226-241.

Hogarth M Jeanne, Sondra G. Beverly and Marianne Hilgert.(2003). Federal Reserve System Community Affairs Research Conference Patterns of Financial Behaviors:Implications for Community Educators and Policy Makers. Federal Reserve System Community Affairs Research Conference 
Hogarth, J.M. (2002). Financial Literacy and Family and Consumer Sciences, Journal of Family and Consumer Sciences, Vol 94, No 1, pp 15-28.

Jamal, A. A. Abdul, Wijaya Kamal Ramlan, MohdRahimie Abdul Karim, RosleMohidin, Zaiton Osman. (2015). The Effects of Social Influence and Financial Literacy on Savings Behavior: A Study on Students of Higher Learning Institutions in Kota Kinabalu, Sabah. International Journal of Business and Social Science Vol. 6, No. 11(1).

Jorgensen, B.L.(2007). Financial Literacy of College Students: Parental and Peer Influences. Unpublished Master Thesis. Virginia Polytechnic Institute and State University: Virginia.

Kholilah Naila Al, Rr. Iramani. (2013). Studi Financial Management Behavior Pada MAsyarakat Surabaya.Journal of Business and Banking. Volume 3, No. 1, May 2013, pages $69-80$

Lusardi, A.,Mitchell, O.S. (2007). Financial Literacy and Retirement Preparedness.Evidence and Implications for Financial Education.Business Economics Vol 42, No 1, pp 35-44

Lusardi, Annamaria. (2005). Financial Education and the Saving Behavior of African-American and Hispanic Households.Research of U.S. Department of Labor, Employee Benefits SecurityAdministration.

Mahdzan, Nurul Shahnaz, Saleh Tabiani. (2013). The Impact of Financial Literacy on Individual Saving: an Exploratory Study in the Malaysian Context". Transformation ini Business and Economics. Vol 12, No1 (28), pp 41-55.

Merauke dalam Angka 2015

Merauke dalam Angka 2014

Ozmete, Emine, Tahira Hira. (2011). Conceptual Analysis of Behavioral Theories/Models: Application to Financial Behavior.European Journal of Social Sciences - Volume 18, Number 3.

Peraturan Presiden Nomor 2 Tahun 2015

Sallik, Maryann, Isabella Adams, Siva Ram Vemuri. (2004). Strategies for Improving Indigenous Financial Literacy in School.Australian Journal of Indigenous Education Volume 33. P.31-36

Shim, S., Barber, B. L., Card, N. A., Xiao, J. J., \& Serido, J. (2010). Financial socialization of first-year college students: The roles of parents, work, and education. Journal of Youth and Adolescence, 39(12), 1457-1470.

Webley, P., \& Nyhus, E. K. (2006).Parents' influence on children's future orientation and saving.Journal of Economic Psychology, 27(1), 140-164

Walker, C. M. 1996.Financial management, coping and debt in households under financial strain.Journal of Economic Psychology, 17(6), 789-807 